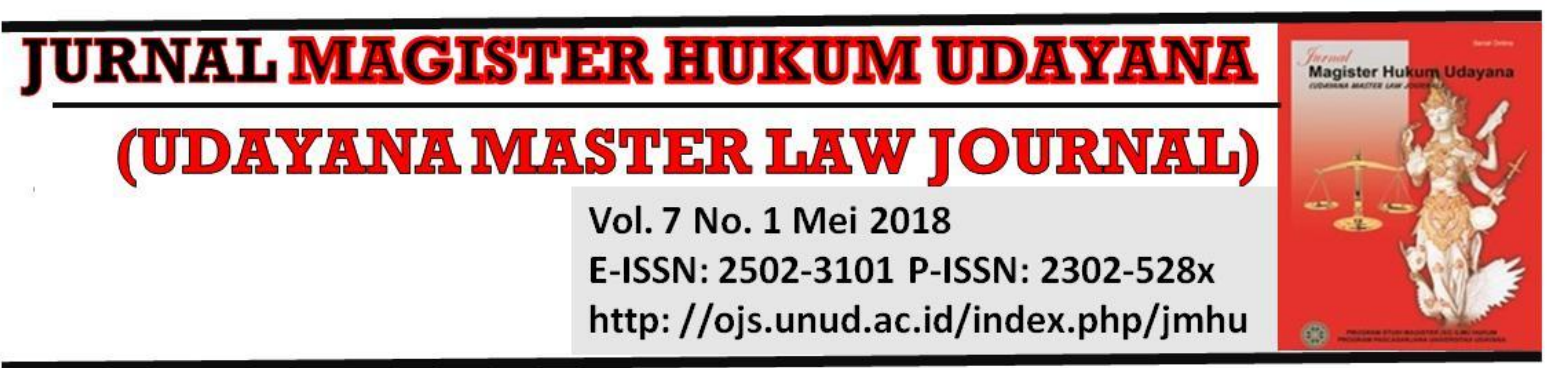

\title{
Efektivitas Undang-Undang Merek dan Indikasi Geografis terhadap Daftar Merek Usaha Dagang Industri Kecil dan Menengah
}

\author{
Irene Svinarky ${ }^{1}$, Ukas $^{2}$, Padrisan Jamba ${ }^{3}$
}

\begin{abstract}
${ }^{1}$ Fakultas Sosial Humaniora dan Ilmu Hukum Universitas Putera Batam,
E-mail: irene.svinarkysh.mkn@gmail.com

2Fakultas Sosial Humaniora dan Ilmu Hukum Universitas Putera Batam, E-mail: ukasibrahim@gmail.com

${ }^{3}$ Fakultas Sosial Humaniora dan Ilmu Hukum Universitas Putera Batam,

E-mail: padri_themasterlaw@yahoo.com
\end{abstract}

\begin{tabular}{l}
\hline Info Artikel \\
\hline Masuk : 18 Mei 2018 \\
Diterima : 27 Mei 2018 \\
Terbit : 28 Mei 2018 \\
Keywords : \\
Effectiveness, brand list, small \\
enterprise and intermediate \\
\\
\\
\\
\\
\\
Kata kunci: \\
Efektifitas, daftar merek, usaha \\
kecil dan menengah. \\
Corresponding Author: \\
Irene Svinarky, E-mail: \\
irene.svinarkysh.mkn@gmail.co \\
m \\
DOI : \\
p0.24843/JMHU.2018.v07.i01. \\
p06
\end{tabular}

\begin{abstract}
There are not easy for new companies to build a reputation or brand image. The company still needs trust first from the community that used their products. Trademark have a very important role, especially in maintaining fair business competition, because the brand can be a differentiating force for one company with another company. The purpose of this study to know the awareness of communities concerning the importance of registering the Trademark based on Law No. 20 of 2016 on Trademark and Geographical Indications. This study uses the method of empirical legal research with sociological jurisprudence approach, as well as data analysis using qualitative analysis. The study shows that the lack of company awareness in understanding the importance of trademark registration, they do not understand the benefits of registering trademark. Communities who set up businesses tend do not registering their trademark, one of the reason is caused by highly cost. As a result, the implementation of the Trademark Law becomes less effective in practice.
\end{abstract}

\begin{tabular}{l} 
Abstrak \\
\hline Perusahaan yang baru berkembang tidak tidak mudah \\
membangun reputasi atau brand image. Perusahaan masih \\
membutuhkan kepercayaan terlebih dahulu dari \\
masyarakat pengguna mereknya. Merek memiliki peran \\
yang sangat penting terutama dalam menjaga persaingan \\
usaha yang sehat, karena merek dapat menjadi daya \\
pembeda bagi satu perusahaan dengan perusahaan lain. \\
Tujuan tulisan ini untuk mengetahui kesadaran \\
masyarakat akan pentingnya mendaftarkan merek \\
berdasarkan Undang-Undang Nomor 20 Tahun 2016 \\
tentang Merek Dan Indikasi Geografis. Penulisan ini \\
menggunakan metode penelitian hukum empris dengan \\
pendekatan sociological jurisprudence, serta analisa data
\end{tabular}




\begin{tabular}{l}
\hline menggunakan analisis kualitatif. Hasil penelitian \\
menunjukkan bahwa masih kurangnya/kesadaran \\
masyarakat dalam memahami penting pendaftaran merek, \\
mereka tidak memahami manfaat pendaftaran merek. \\
Masyarakat cenderung mendirikan usaha dengan tidak \\
mendaftarkan mereknya, salah satu faktornya adalah biaya \\
yang sangat mahal, sehingga menyebabkan implementasi \\
ketentuan merek menjadi kurang efektif di dalam \\
prakteknya.
\end{tabular}

\section{Pendahuluan}

Pembangunan suatu usaha memperkenalkan produk barang kepada konsumen, bukanlah hal yang mudah bagi pelaku usaha. Pelaku usaha harus memperkenalkan kepada publik dengan cara promosi terhadap produknya yang belum dikenal umum. Untuk membuat suatu produk itu menjadi dikenal oleh umum maka harus diimbangi dengan merek yang sesuai dengan aturan hukum, agar merek yang diperkenalkan tersebut tidak mengganggu merek pengusaha lainnya. Upaya membudayakan penghargaan terhadap Hak atas Kekayaan Intelektual (HKI) yang sekarang juga singkatannya dikenal dengan sebutan KI harus bersama dengan meningkatkan perlindungan hukum atas hak-hak tersebut, melalui perangkat hukum dan mekanisme perlindungan yang memadai. HKI merupakan hak yang diberikan oleh pemerintah bagi pengusaha-pengusaha baik perorangan maupun yang berbadan hukum terhadap kekreatifannya untuk menghasilkan karya-karya inovatif yang dapat diterapkan dalam kehidupan manusia. Bagi para pencipta dan penemu, begitu juga pemilik merek, juga diberikan haknya oleh pemerintah berupa hak yang ada di dalam HKI.

Keberadaan Undang-Undang Nomor 20 Tahun 2016 tentang Merek Dan Indikasi Geografis dalam era perdagangan global, tampaknya sudah sejalan dengan konvensikonvensi internasional yang telah diratifikasi Indonesia. Peranan merek menjadi sangat penting terutama dalam menjaga persaingan usaha yang sehat. Pada Pasal 1 ayat 5 Undang-Undang Merek Dan Indikasi Geografis tersebut, dapat difahami bahwasannya pengaturan yang memadai tentang merek, bermanfaat untuk memberikan peningkatan pelayanan bagi masyarakat termasuk dalam pengurusan izin yang diberikan oleh pemerintah. Dalam hal ini, sesungguhnya pemerintah sudah memberikan perhatiannya kepada masyarakat melalui ketentuan merek yang berlaku sebelumnya yaitu Undang-Undang Nomor 15 Tahun 2001 tentang Merek, yang kemudian di tahun 2016 undang-undang tersebut diganti dengan Undang-Undang Nomor 20 Tahun 2016 tentang Merek Dan Indikasi Geografis. Pergantian ini merupakan penyempurnaan undang-undang sebelumnya dimana di undang-undang lama hanya sedikit di dalam pasalnya mengatur Indikasi Geografis yang sering disebut dengan IG, padahal saat sekarang ini kementerian Hukum Dan Ham sangat gencar-gencarnya mengembangkan tentang IG ke wilayah-wilayah seluruh Indonesia.

Dengan memahami keberadaan Undang-Undang tentang Merek Dan Indikasi Geografis secara lebih mendalam, akan sangat bermanfaat bagi perusahaan pemilik merek, mereka dapat menyebarluaskan mereknya dengan cara publikasi baik melalui media cetak, dan atau media elektronik lainnya. Semakin pesatnya persaingan usaha 
baik di dalam perdagangan nasional maupun dalam perdagangan internasional dalam perdagangan barang dan jasa, maka tidak terlalu berlebihan kalau dikemukakan bahwa merek itu memiliki peranan yang signifikan untuk dikenali sebagai tanda suatu produk dan atau jasa tertentu. Di kalangan masyarakat dan juga memiliki kekuatan dan manfaat apabila dikelola dengan baik, hal tersebut sesuai pendapat Bambang Kosowo bahwa "Merek itu mempunyai nilai atau ekuitas, ekuitas menjadi sangat penting karena nilai tersebut menjadi tolak ukur suatu produk yang dipasarkan. Lebih lanjut Bambang mengemukakan bahwa fungsi merek lebih berkembang dalam dunia usaha $^{1}$ sehingga membeli produk pesaingnya tersebut yang kiranya produk dari perusahaan sebenarnya.

Fenomena seperti tersebut di atas, tidak hanya mengurangi keuntungan perusahaan dan membuat bingung pelanggannya, tetapi juga dapat merusak reputasi dan citra perusahaan yang bersangkutan khususnya apabila produk pesaing kualitasnya lebih rendah. Fungsi merek dari sebuah merek adalah agar konsumen dapat mencirikan suatu produk (baik barang maupun jasa) untuk memiliki hak perusahaan sehingga dapat dibedakan dari produk perusahaan lain yang serupa atau mirip yang dimiliki oleh pesaingnya. Konsumen yang merasa puas dengan suatu produk tertentu biasanya akan membeli dengan atau memakai produk-produk tersebut di masa yang akan datang. Merek juga dapat menjadi nilai tambah bagi perusahaan untuk berinvestasi dalam meningkatkan kualitas produk yang mereka miliki agar menjamin merek produk mereka yang memiliki reputasi yang baik. Hal ini terbukti bahwa beberapa merek terkenal seperti sepatu, sandal yang mempunyai kualitas yang bagus senantiasa berinvestasi dan membangun produk mereka dengan beberapa model dan inovasi yang mutakhir sehingga masyarakat sudah meyakini kualitas dari produk tersebut memang diakui.

Menurut Adil Samadani dalam buku Dasar-dasar Hukum Bisnis menyebutkan bahwa pentingnya penggunaan merek untuk membedakan produk yang mereka miliki dengan produk para pesaing mereka, oleh karenanya menjadi penting merek tersebut mendapat perlindungan atau melalui pendaftaran 2 . Adanya pendaftaran merek, investasi yang dimiliki dalam memasarkan sebuah produk dapat menjadi suatu yang sifatnya sia-sia, karena perusahaan pesaing dapat memanfaatkan merek yang sama atau merek yang mirip tersebut untuk membuat atau memasarkan produk yang identik atau mirip dan pelanggan dapat menjadi bingung.

HKI timbul atau lahir karena adanya intelektualitas seseorang sebagai inti atau objek pengaturannya. Pemahaman terhadap hak ini pada dasarnya merupakan pemahaman terhadap hak atas kekayaan yang timbul atau lahir dari intelektualitas manusia. Banyak karya-karya yang lahir atau dihasilkan oleh manusia melalui intelektualitas, baik melalui daya cipta, rasa dan karsa. Perlindungan hukum terhadap hasil intelektualitas manusia dibanding teknologi, ilmu pengetahuan, seni, sastra dan lainlain perlu diperhatikan dengan serius sebab karya manusia ini telah dihasilkan dengan suatu pengorbanan tenaga, pikiran, waktu, bahkan biaya yang tidak sedikit, termasuk

\footnotetext{
${ }^{1}$ Bambang, K. (2003). HAKI (Hak Atas Kekayaan Intelektual). Jakarta. Penerbit Sinar Grafika. h. 16. 2 Adil, S. (2013). Dasar-Dasar Hukum Bisnis. Bandung. Mitra Wacana Media. h. 129.
} 
di dalamnya dalam bidang Hak Cipta. ${ }^{3}$ Pengorbanan demikian tentunya menjadikan karya yang dihasilkan memiliki nilai yang patut dihargai, ditambah lagi dengan adanya manfaat yang dapat dinikmati yang dari sudut ekonomi karya-karya seperti ini tentunya memiliki nilai ekonomi yang tinggi.

Menurut Farida Hasyim konsep berfikir seperti di atas, timbul pikiran untuk menumbuhkan dan mengembangkan sistem perlindungan hukum atas intelektualitas manusia4. Dalam sejarah memang harus diakui bahwa konsep perlindungan hukum HKI bukan merupakan hal yang timbul dalam sistem hukum kita, konsep ini pertama tumbuh dan dikembangkan dalam sistem hukum asing. HKI sebagai kekayaan (property) dalam konsep hukum perdata selalu diartikan sebagai benda berwujud yang dapat dijadikan objek dari perjanjian. Dalam perkembangan selanjutnya, kekayaan yang didapat dilihat, bahwa ada suatu kekayaan yang tidak berwujud yaitu kekayaan yang bersumber dari kemampuan manusia, karena faktor budaya komunal dianggap suatu yang biasa dipergunakan dan dimanfaatkan oleh sesama. Padahal untuk menghasilkan karya tersebut seseorang telah mengorbankan tenaga, waktu dan bahkan materi dengan demikian karya tersebut sesungguhnya mempunyai nilai ekonomis. Perlindungan HKI baik Merek maupun hak Cipta menganut konsep perlindungan Individual Rights, yang artinya memberi perlindungan berupa hak eksklusif kepada pencipta atau pemilik HKI yang telah mengorbankan tenaga, fikiran dan waktunya untuk menghasilkan karya yang bernilai dan bermanfaat. ${ }^{5}$

HKI adalah hak-hak hukum yang diperoleh dari aktivitas intelektual dibidang industri, ilmu pengetahuan dan seni yang meliputi hak dalam bidang seni, hak kepemilikan industri, merek dan hak-hak lainnya. Hak atas merek berdasarkan Undang-Undang Nomor 20 Tahun 2016 tentang Merek Dan Indikasi Geografis, berdasarkan Pasal 1 ayat (1) berbunyi: Merek adalah tanda yang dapat ditampilkan secara grafis berupa gambar, logo, nama, kata, huruf, angka, susunan warna, dalam bentuk 2 (dua) atau lebih unsur tersebut untuk membedakan barang dan/jasa yang diproduksi oleh orang dan/atau jasa yang diproduksi oleh orang atau badan hukum dalam kegiatan perdagangan barang dan/saja. Esensi penting dari Merek sebagai berikut: 1). Merek merupakan tanda yang digunakan untuk membedakan produk barang dan atau jasa tertentu dengan yang lainnya dalam rangka memperlancar perdagangan, menjaga kualitas dan melindungi produsen dan konsumen; 2)Merek adalah tanda yang berupa gambar, nama, kata, huruf, angka dari unsur-unsur tersebut yang memiliki daya pembeda dan digunakan perdagangan barang atau jasa; serta 3). Merek sebagai salah satu bagian dari hak atas kekayaan intelektual manusia sangat penting terutama dalam menjaga persaingan usaha yang sehat.

Fungsi merek sebagai tanda pengenal untuk membedakan hasil produksi yang dihasilkan seseorang atau beberapa orang secara bersama-sama atau badan hukum dengan produksi orang lain atau badan hukum lainnya sebagai alat promosi.

3 Ardian, Agnes Vira. "Prospek Perlindungan Hukum Hak Kekayaan Intelektual Dalam Kesenian Tradisional Di Indonesia." PhD diss., program Pascasarjana Universitas Diponegoro, 2008, h. 90

${ }^{4}$ Farida, H. (2009). Hukum Dagang. Bandar Lampung. Penerbit Sinar Grafika. h. 185.

${ }^{5}$ Dharmawan, N. K. S. (2017). Protecting Traditional Balinese Weaving Trough Copyright Law: Is It Appropriate?. Diponegoro Law Review, 2(1).

DOI: https://doi.org/10.14710/dilrev.2.1.2017.57-84 
Mempromosikan hasil produksinya cukup dengan menyebut mereknya sebagai jaminan atas mutu barangnya, dan menunjukan asal barang atau jasa yang dihasilkannya. Dalam Undang-Undang Merek di Indonesia juga diatur perlindungan Indikasi Geografis. Berkaitan dengan aspek perdagangan internasional, penggunaan nama geografis sebagai petunjuk atau indikasi dari suatu barang itu berasal, memiliki keunggulan komparatif (comparative advantage) yang mampu meningkatkan daya saing (competitiveness) komoditas yang bersangkutan., sehingga sangat penting mengatur perlindungannya termasuk melalui perjanjian internasional secara multilateral. 6

Adil Sawadani dalam bukunya Dasar-Dasar Hukum Bisnis, menyebutkan beberapa istilah-istilah dalam hak merek yaitu: ${ }^{7}$

1. Merek dagang adalah merek yang dipergunakan pada barang yang diperdagangkan oleh seseorang secara bersama-sama atau badan hukum untuk membedakan barang-barang sejenis lainnya.

2. Merek jasa yaitu merek yang digunakan pada barang atau jasa yang diperdagangkan oleh seseorang atau beberapa orang secara bersama-sama atau badan hukum untuk membedakan dengan jasa-jasa sejenis lainnya.

3. Merek kolektif adalah merek yang digunakan pada barang atau jasa dengan karakteristik yang sama yang diperdagangkan oleh beberapa orang atau badan hukum secara bersama-sama untuk membedakan dengan barang atau jasa sejenis lainnya.

4. Hak atas merek adalah hak khusus yang diberikan Negara kepada pemilik merek yang terdaftar dalam daftar umum merek untuk jangka waktu tertentu, menggunakan sendiri merek tersebut atau memberi izin kepada seseorang atau beberapa orang secara bersama-sama atau badan hukum untuk menggunakannya.

Pengajuan merek hanya dapat diajukan untuk satu kelas barang atau jasa, kelas atau jasa dalam kelompok jenis barang atau jasa yang mempunyai persamaan dalam sifat, cara pembuatan dan tujuan penggunaannya. Apabila merek akan dimintakan pendaftarannya untuk lebih dari satu kelas, maka permintaan akan pendaftarannya harus diajukan secara terpisah. Berdasarkan latar belakang dalam penelitian ini, Tim Peneliti tergugah dan termotivasi memberi judul dalam penelitian ini yaitu “Efektivitas Undang-Undang Nomor 20 Tahun 2016 Tentang Merek Dan Indikasi Geografis Terhadap Daftar Merek Usaha Dagang Industri Kecil Dan Menengah". Berdasarkan uraian di atas dapat ditarik permasalahannya sebagai berikut: Bagaimanakah menumbuhkan kesadaran masyarakat untuk mendaftarkan merek berdasarkan Undang-Undang Nomor 20 Tahun 2016 tentang Merek Dan Indikasi Geografis?

Tulisan ini merupakan hasil karya ilmiah yang disusun dari hasil penelitian hibah internal dari tim peneliti. Beberapa studi terdahulu yang juga berkaitan dengan Merek dan Indikasi Geografis, namun fokus berbeda diantaranya: Y Sumiyati dan Taty Ramly mengkaji tentang pentingnya kebijakan Pemerintah Daerah sebagai bentuk dan tanggung jawab dalam melindungi produk indikasi geografis dalam rangka

\footnotetext{
${ }^{6}$ Sasongko, W. (2012). Indikasi Geografis: Rezim Hki Yang Bersifat Sui Generis. Jurnal Media Hukum, 19(1). h. 101.

7 Adil, S. Op. Cit. h. 145.
} 
memberikan rasa keadilan dan manfaat ekonomi kepada masyarakat. ${ }^{8}$ Studi yang berkaitan dengan perubahan aturan hukum terkait perlindungan Indikasi Geografis dalam bentuk kajian focus discussion group khususnya bagi masyarakat pelestari padi Pandanwangi Cianjur. ${ }^{9}$

\section{Metode Penelitian}

Adapun metode penelitian yang digunakan adalah penelitian empiris dengan menggunakan pendekatan sociological jurisprudence. Sociological jurisprudence yaitu bagian dari suatu mazhab dalam filsafat hukum yang mempelajari pengaruh timbal balik antara hukum dan masyarakat ${ }^{10}$. Dalam melakukan suatu penelitian para peneliti membutuhkan sebuah metode (desain penelitian) dalam hal ini menggunakan penelitian kualitatif tentunya proposal penelitian ini menyesuaikan kebutuhan suatu penelitian, sehubungan hal tersebut desain penelitian ini nantinya menggunakan metode kualitatif. Dalam penelitian kualitatif yang bertolak dari data, memanfaatkan teori yang ada sebagai bahan penjelasan, dan berakhir dengan suatu teori, atau yang disebut desain penelitian. Sehubungan hal tersebut di atas, penelitian dalam menyusun dan atau melakukan penelitian ini penelitian nantinya akan menggunakan desain kualitatif. Dalam penelitian kualitatif bertolak dari data yang ada memanfaatkan data yang ada sebagai bahan penjelasan dan berakhir dengan suatu teori.

Menurut Nazir11 penelitian adalah suatu proses mencari sesuatu yang sistematis dalam waktu yang lama dengan menggunakan metode ilmiah serta aturan-aturan yang berlaku. Desain penelitian adalah suatu proses yang diperlukan dalam perencanaan penelitian, dalam pengertian yang sempit, desain penelitian hanya mengenai pengumpulan data dan analisis saja, dan dalam pengertian yang lebih luas desain penelitian adalah mencakup proses-proses yaitu sebagai berikut : Identifikasi masalah, Pemilihan kerangka konsepsional untuk masalah penelitian serta hubungan-hubungan dengan penelitian sebelumnya, Merformulasikan masalah penelitian termasuk membuat spesifikasi tujuan luas jangkauan(scope) hipotesis untuk diuji, Membangun definisi penyelidikan atau percobaan, Memilih serta memberikan definisi terhadap pengukuran batas wilayah, Memilih prosedur pengamatan secara langsung, Menyusun alat serta teknik untuk mengumpulkan data, serta Menganalisis data serta mengadakan pelaporan hasil penelitian, termasuk proses penelitian, diskusi serta interpretasi data, generalisasi, kekurangan-kekurangan dalam penemuan, serta menganjurkan beberapa saran-saran dan kerja penelitian yang akan datang.

Lokasi penelitian merupakan bagian dari pada rangkaian penelitian di dalam memperoleh informasi dan jawaban mengenai data-data dari permasalahan yang

8 Sumiyati, Y., Ramli, T. A., \& Iskandar, R. K. (2008). Kajian Yuridis Sosiologis mengenai Indikasi Geografis sebagai Sumber Pendapatan Asli Daerah (PAD). MIMBAR, Jurnal Sosial dan Pembangunan, 24(1), 79-88.

9 Aridhayandi, M. R. (2017). Focus Group Discution Mengenai Pemahaman Perubahan Aturan Hukum Indikasi Geografis Bagi Masyarakat Pelestari Padi Pandanwangi Cianjur (Mp3c) Sebagai Pemegang Hak Indikasi Geografis Terdaftar. Journal of Empowerment, 1(2), 89.

10 Johnny, I. (2008) Teori dan Metodologi Penelitian Hukum Normatif. Malang: Bayumedia Publishing. h. 40.

${ }^{11}$ Nazir, Mohammad. (2002). Metode Penelitian, Jakarta: Penerbit Ghalia Indonesia. h. 84. 
menjadi objek penelitian ini. Lokasi penelitian ini yaitu: Di Kantor Dinas Perindustrian dan Perdagangan Kota Batam (Disperindag) Kota Batam, tepatnya lantai V Kantor Bersama Batam Center dan pada Pelaku usaha yang mendaftarkan usahanya di Kota Batam (Sample), baik industri Kecil maupun Menengah.

\section{Hasil dan Pembahasan}

\subsection{Pengaturan Perlindungan Merek Berdasarkan Undang-Undang Nomor 20 Tahun 2016 Tentang Merek Dan Indikasi Geografis}

Pendaftaran merek sangat dibutuhkan untuk masyarakat mendapatkan kepastian hukum terhadap barang yang di produksi dari sebuah perusahaan, sehubungan dengan hal tersebut penting sekali adanya pemahaman dan kesadaran masyarakat yang memiliki perusahaan untuk mendaftarkan mereknya. Dalam Undang-Undang Nomor 20 Tahun 2016 tentang Merek Dan Indikasi Geografis tidak ada penjelasan baku mengenai gambar, nama, kata, huruf, angka serta susunan warna namun dalam praktiknya yang dimaksud dengan gambar, nama, kata, huruf, serta susunan warna di dapat dalam website ${ }^{12}$ :

1. Perlindungan atas merek

Hak atas merek adalah Hak Eksklusif yang diberikan Negara kepada "Pemilik merek yang terdaftar" dalam daftar umum merek untuk jangka waktu tertentu menggunakan sendiri merek tersebut atau memberi izin kepada seseorang atau beberapa orang secara bersama-sama atau badan hukum untuk menggunakannya.

2. Hal yang penting perlu untuk diketahui

Perlindungan atas merek terdaftar yaitu adanya kepastian hukum atas merek terdaftar baik untuk digunakan, diperpanjang, dialihkan dan dihapus sebagai alat bukti apabila nantinya terjadi sengketa pelanggaran atas merek terdaftar. Dalam hal ini, adapun hal yang harus diketahui antara lain status pendaftaran, jangka waktu perlindungan, mutasi dan lisensi, pelanggaran dan sanksi.

Adapun masing-masing penjabarannya adalah sebagai berikut:

a. Status pendaftaran

Indonesia mengenal atau menganut asas konstitutif yaitu: hak atas merek diperoleh atas pendaftarannya, artinya pemegang hak merek adalah seseorang yang mendaftarkan untuk pertama kalinya di Direktorat Jendral Hak Kekayaan Intelektual.

b. Jangka waktu perlindungan

Jangka waktu perlindungan merek 10 tahun terhitung sejak tanggal penerimaan pendaftaran (filling date). Setelah 10 tahun dapat diperpanjang kembali.

c. Mutasi dan lisensi

Pengertian mutasi meliputi pengalihan dan perubahan nama atau alamat. 1 . Pengalihan hak dalam hal ini dilakukan dengan 4 cara yaitu: a. Pewarisan, b. Wasiat, c. Hibah, d. Perjanjian dan sebab-sebab lain sesuai dengan undang-undang. 2. Lisensi adalah izin yang diberikan pemilik merek terdaftar kepada seseorang atau beberapa orang secara bersama-sama atau badan hukum untuk menggunakan merek tersebut, baik untuk seluruhnya ataupun sebagian jenis barang atau jasa yang didaftarkan.

12 Ukas., Irene, S. \& Jamba, P. (2017). Jurnal Cahaya Keadilan . Vol 5. No. 1 ISSN: 2339-1693. Jurnal Cahaya Keadilan, 5(1), 29-47. Retrieved from ejournal.upbatam.ac.id. 2017. 
d. Pelanggaran dan sanksi

1) Barang siapa dengan sengaja dan tanpa hak menggunakan merek yang sama pada keseluruhannya dengan merek terdaftar milik pihak lain untuk barang dan/atau jasa sejenis yang diproduksi dan atau diperdagangkan, dipidana dengan pidana penjara paling lama 5 (lima) tahun dan/atau denda paling banyak Rp. 1.000.000.000 (satu miliar rupiah).

2) Barang siapa dengan sengaja dan tanpa hak menggunakan merek yang sama pada pokoknya dengan merek terdaftar milik pihak lain untuk barang dan atau jasa sejenis yang diproduksi dan atau diperdagangkan, dipidana dengan pidana penjara paling lama 4 (empat) tahun dan/atau denda paling banyak Rp. 800.000 .000 (delapan ratus juta rupiah). ${ }^{13}$

Berkaitan dengan perlindungan merek, pengaturan tentang prosedural pendaftaran merek juga merupakan hal yang sangat esensi, selain hal-hal yang berkaitan dengan pelanggaran maupun sanksi hukum bagi pihak yang melanggar merek. Di Indonesia, merek termasuk dalam rezim Hak atas Kekayaan Industrial (Industrial Property Rights) yang system perlindungan hukumnya menganut "first to file system" atau Sistem Konstitutif, artinya pendaftar yang lebih dahulu diberikan perlindungan hukum atau sistem pendaftaran ini didasarkan pada pendaftaran pertama. ${ }^{14}$ Pendaftaran merek juga sangat penting dalam rangka pengembangan bisnis waralaba, seperti contohnya sistem waralaba ayam goreng kaki lima yang dikembangkan oleh masyarakat yang diinspirasi oleh waralaba yang telah memiliki perlindungan hukum yang tetap dan jelas seperti KFC. Sehubungan dengan pengembangan bisnis waralaba dapat dipastikan apabila HKI dari pemilik waralaba tidak terdaftar maka usahanya tidak akan dapat dikembangkan dalam bentuk waralaba dan tidak terlindungi secara hukum., oleh karenanya HKI dalam waralaba harus mendapatkan perlindungan hukum. ${ }^{15}$ Persyaratan yang harus dilengkapi berkaitan dengan pengajuan Pendaftaran Merek Usaha adalah sebagai berikut:

1. Mengajukan permohonan pendaftaran merek dengan melampirkan:

a. Formulir pendaftaran merek yang telah disediakan oleh disperindak rangkap 4 (empat) terlebih dahulu harus diisi.

b. Surat pernyataan kepemilikan merek juga diberikan materai Rp. 6000,- (enam ribu rupiah).

c. Melampirkan fotokopi pihak yang mendaftarkan mereknya.

d. Apabila merek tersebut berasal dari badan hukum maka melampirkan fotokopi akta pendirian badan hukum yang dilegalisir oleh notaris.

e. Fotokopi NPWP Pribadi apabila orang pribadi yang mendirikan, sedangkan fotokopi pribadi + dengan fotokopi badan usaha juga harus dilampirkan apabila merek berasal dari badan usaha.

f. Etiket merek sebanyak 26 (dua puluh enam) lembar dengan ukuran maksimal $9 \times 9 \mathrm{~cm}$ dan minimal $2 \times 2 \mathrm{~cm}$.

g. Contoh fisik produk yang didaftarkan.

13 Ibid.

14 Kurniawan, I. G. A. (2013). Pengaturan Penghentian Pemakaian Indikasi Geografis Pada Merek Terdaftar Oleh Pihak Lain Yang Tidak Berhak (Studi Komparatif Beberapa Negara). Jurnal Magister Hukum Udayana (Udayana Master Law Journal), 2(2). h. 6.

15 Hanim, L. (2018). Perlindungan Hukum Haki dalam Perjanjian Waralaba di Indonesia. Jurnal Hukum, 26(2), 575- 576 
2. Pemeriksaan permintaan pendaftaran merek

Di dalam pendaftaran merek, pihak pengusul harus mengikuti prosedur pemeriksaan formal dan pemeriksaan substansif. Adapun penjabarannya adalah sebagai berikut:

a. Pemeriksaan formal, pemeriksaan atas kelengkapan persyaratan administratif yang ditetapkan.

b. Pemeriksaan substansif, pemeriksaan terhadap merek yang diajukan apakah dapat didaftarkan atau tidak, berdasarkan persamaan pada keseluruhan, persamaan pada pokoknya, atas merek sejenis milik orang lain, sudah diajukan mereknya lebih dahulu oleh orang lain.

\subsection{Kesadaran Masyarakat Untuk Pentingnya Mendaftarkan Merek Berdasarkan Undang-Undang Nomor 20 Tahun 2016 Tentang Merek Dan Indikasi Geografis}

Merek sebagai salah satu bagian dari hak atas kekayaan intelektual manusia yang sangat penting terutama dalam menjaga persaingan usaha yang sehat. Oleh karena itu, masalah merek perlu diatur dalam suatu undang-undang yang khusus mengenai merek, yaitu dengan Undang-Undang Nomor 15 Tahun 2001 tentang Merek yang menggantikan undang-undang sebelumnya yaitu Undang-Undang Nomor 19 Tahun 1992 sebagaimana telah diubah dengan Undang-Undang Nomor 14 Tahun 1997 diubah lagi dengan Undang-Undang Nomor 15 Tahun 2001. Kemudian di Undangkannya Undang-Undang Nomor 20 Tahun 2016 tentang Merek Dan Indikasi Geografis yang merupakan pergantian dari Undang-Undang Nomor 15 Tahun 2001 tentang Merek.

Di dalam Pasal 1 ayat (5) Undang-Undang Nomor 20 Tahun 2016 Tentang Merek Dan Indikasi Geografis, menyatakan bahwa hak atas merek adalah hak ekslusif yang diberikan oleh negara kepada pemilik Merek yang terdaftar dalam Daftar Umum Merek untuk jangka waktu tertentu dengan menggunakan sendiri merek tersebut atau memberikan izin kepada pihak lain untuk menggunakannya. Berdasarkan Pasal 1 ayat (9) berbunyi pihak yang mengajukan Merek atau Indikasi Geografis yang dimaksud pemohon adalah Pihak yang mengajukan Permohonan merek. Adapun di Pasal 9 yang menyatakan bahwa: Pemohon dengan menggunakan Hak Prioritas harus diajukan dalam waktu lama 6 (enam) bulan terhitung sejak Tanggal Penerimaan permohonan pendaftaran Merek yang pertama kali diterima di negara lain yang merupakan anggota Konvensi Paris tentang Perlindungan Kekayaan Industri (Paris Convention for the Protection of Industrial Property) atau anggota Persetujuan Pembentukan Organisasi Perdagangan Dunia (Agreement Establishing the World Trade Organization).

Merek diberikan kepada pemohon yang beritikad baik, yaitu pemohon yang mendaftarkan mereknya secara layak dan jujur tanpa ada niat apapun untuk membonceng, meniru atau menjiplak ketentraman merek pihak lain menimbulkan kondisi persaingan curang, membohongi atau menyesatkan konsumen. Di dalam tulisan ini Tim memberikan contoh sebagai berikut: merek dagang milik $X$ sudah dikenal oleh masyarakat, kemudian merek tersebut digunakan oleh pengusaha lain untuk medongkrak usahanya, sehingga mempunyai persamaan pokoknya atau keseluruhannya dengan merek $X$ tersebut. Dalam hal ini pemilik usaha yang baru tidak memiliki itikad baik, karena sudah meniru merek dagang produk lain. Contoh yang diberikan tersebut harus diketahui unsur apa yang membuat kesengajaan produk 
merek dagang yang telah dikenal tersebut di masyarakat ditiru oleh pihak lain. Adapun hal hasil wawancara yang didapatkan penulis dari penelitian ini adalah mengenai itikad tidak baik yang telah diupayakan oleh pemerintah untuk penanganan permasalahan. Dalam penelitian ini Dinas Perindustrian, perdagangan, energi dan Sumber Daya Mineral Kota Batam banyak menjelaskan merujuk kepada UndangUndang Nomor 20 Tahun 2016 yang diganti dari Undang-Undang Nomor 15 Tahun 2001 tentang Merek dimana dinas tersebut melakukan pengupayaan kepada pengusaha, baik pribadi ataupun badan hukum, antara lain:

1. Dinas Perindustrian, perdagangan, energi dan Sumber Daya Mineral Kota Batam, telah mengusahakan pemberian sosialisasi kepada pengusaha-pengusaha yang mendaftarkan mereknya dalam bentuk bimbingan teknis, prosedural pendaftaran merek.

2. Selain itu di waktu senggang ketika membeli suatu produk ke masyarakat beberapa pegawai dinas tersebut berusaha untuk memberitahukan kepada masyarakat pentingnya pendaftaran merek terhadap produk mereka dan menegur merek pengusaha yang mencontoh merek milik pengusaha lain.

3. Pengusaha yang telah melakukan pendaftaran merek akan mendapatkan nantinya sebuah sertifikat merek. Jangka waktu lamanya keluar sertifikat merek tidak diambil oleh pemilik merek sejak tanggal penerbitan sertifikat berdasarkan Undang-Undang Nomor 20 Tahun 2016 tentang Merek Dan Indikasi Geografis berdasarkan Pasal 25 ayat (3) adalah selama 18 bulan, sedangkan Di Pasal 35 ayat (1) dan ayat (2) untuk lamanya berlaku perlindungan merek ini selama 10 tahun sejak tanggal penerimaan dan dapat diperpanjang dengan jangka waktu yang sama.

4. Dalam hal ini apabila masih dalam berpatokan di Pasal 22 menyatakan: Terhadap Merek terdaftar yang kemudian menjadi nama generik, setiap orang yang dapat mengajukan Permohonan merek dengan menggunakan nama generik dimaksud dengan tambahan kata lain ada unsur pembeda.

Jenis dan bentuk merek untuk klasifikasi, lisensi dan jenis lainnya.

1. Merek usaha yang paling dominan adalah merek dagang, bank, pangan khususnya di Kota Batam. Pendaftaran merek usaha yaitu di Kementerian Hukum Dan HAM dan Dirjen Kekayaan Intelektual.16

2. Kendala yang dihadapi pemerintah (Disperindag Kota Batam tentang pendaftaran merek, masih kurangnya/kesadaran masyarakat memahami penting dan manfaat suatu produk merek yang sudah di daftar termasuk mencari merek-merek usaha apa saja yang khas didaftar selain prosedurnya.

Untuk keefektifan Undang-Undang Nomor 20 Tahun 2016 terhadap Merek Dan Indikasi Geografis, upaya yang dilakukan dinas ini sudah cukup baik. Ada beberapa trik yang Tim Peneliti ajukan agar tugas dari dinas berjalan dengan maksimal. Adapun trik tersebut, berupa memberikan surat teguran kepada pengusaha yang masih nakal dan tidak mendaftarkan mereknya. Bekerja sama dengan Kadin (Kamar Dagang Indonesia) agar pengusaha-pengusaha yang mendaftarkan bidang usahanya ke Kadin juga mengurus pendaftaran mereknya ke dinas HKI terkait. Mungkin trik yang Tim Peneliti berikan ini dapat menjadi salah satu solusi agar aturan yang telah ada dapat diperkenalkan di para kalangan pengusaha, agar banyak usaha yang mendaftarkan mereknya ke Disperindag Kota Batam.

16 Ibid. 
Di kalangan masyarakat yang mendirikan usaha, pada dasarnya masyarakat memikirkan barang yang mereka hasilkan dan mereka jual hanya untuk mendapatkan uang pada saat barang itu terjual saja, tetapi satu sisi mereka tidak memikirkan bahwasannya barang yang mereka hasilkan tersebut perlu dilindungi hak mereknya. Alasan pemerintah mengeluarkan aturan ini memang untuk melindungi masyarakat agar merek dari produk yang mereka hasilkan menjadikan daya pembeda antara merek yang satu terhadap suatu produk dengan merek yang lain. Masyarakat cenderung membuat usaha dengan tidak mendaftarkan merek usahanya, dengan alasan biaya yang sangat mahal padahal penjualan tidak seberapa dan banyak lagi alasan lainnya, sehingga aturan yang adapun kurang efektif di dalam prakteknya. Untuk aturan tentang Merek dan IG terhadap sanksi pidana dalam pelanggaran merek pun diperberat khususnya yang mengancam kesehatan manusia, lingkungan hidup dan dapat menyebabkan kematian. Mengingat masalah merek terkait erat dengan faktor ekonomi, dalam undang-undang ini sanksi pidana diperberat.

\section{Kesimpulan}

Berdasarkan hasil penelitian mengenai Kesadaran Masyarakat Untuk Mendaftarkan Merek Usahanya berdasarkan Undang-Undang Nomor 20 Tahun 2016 Tentang Merek Dan Indikasi Geografis belum berjalan efektif di dalam praktek karena UndangUndang Nomor 20 Tahun 2016 tentang Merek dan Indikasi Geografis terhadap pendaftaran merek usaha di Kota Batam karena masih banyak masyarakat yang kurang peduli terhadap peraturan yang ada. Hal ini dapat dilihat dari masih adanya penggunaan merek orang lain contoh : di pada barang tas yang ada di Batam masih ada barang yang KW, KW1, KW super, tetapi penjualannya masih berjalan dan tidak ada laporan dari masyarakat ke Disperindak Kota Batam atau ke Kementerian Hukum Dan HAM. Penggunaan merek orang lain yang mereka suka terkadang tanpa mempertimbangkan kerugian bagi orang lain, yang dilakukan mereka untuk memperoleh keuntungan sendiri. Adapun kendala yang dihadapi: Pengusaha atau pelaku usaha yang menjiplak secara keseluruhan merek orang lain yang sudah terdaftar, tidak memikirkan bahwa ada sanksi hukum yang akan menjerat mereka, apabila ada yang mengajukan pengaduan, serta Pengusaha atau pelaku usaha kurang menyadari tentang hukum. Solusi dalam rangka peningkatan kesadaran masyarakat terkait perlindungan merek dan indikasi geografis yaitu: dilakukan sosialisasi oleh pemerintah termasuk Disperindag, serta bagi pengusaha atau pelaku usaha yang dirugikan harus beranikan diri mengajukan delik aduan kepada pihak yang berwajib ataupun pengadilan apabila pihak yang memiliki merek merasa dirugikan.

\section{Daftar Pustaka \\ Buku}

Samadani, Adil. (2013). Dasa-Dasar Hukum Bisnis. Bandung: Mitra Wacana Media.

Kusowo, Bambang. (2003). HAKI (Hak Atas Kekayaan Intelektual), Jakarta: Penerbit Sinar Grafika.

Hasyim, Farida. (2009). Hukum Dagang. Bandar Lampung: Penerbit Sinar Grafika.

Ibrahim, Johnny. (2008). Teori dan Metodologi Penelitian Hukum Normatif, Malang: Bayumedia Publishing. 
Nazir, Mohammad. (2002). Metode Penelitian, Jakarta: Penerbit Ghalia Indonesia.

\section{Jurnal}

Aridhayandi, M. R. (2017). Focus Group Discution Mengenai Pemahaman Perubahan Aturan Hukum Indikasi Geografis Bagi Masyarakat Pelestari Padi Pandanwangi Cianjur (Mp3c) Sebagai Pemegang Hak Indikasi Geografis Terdaftar. Journal of Empowerment, 1(2), 87-102.

Dharmawan, N. K. S. (2017). Protecting Traditional Balinese Weaving Trough Copyright Law: Is It Appropriate?. Diponegoro Law Review, 2(1). DOI: https:// doi.org/10.14710/dilrev.2.1.2017.57-84

Hanim, L. (2018). Perlindungan Hukum Haki dalam Perjanjian Waralaba di Indonesia. Jurnal Hukum, 26(2), 571-589.

Kurniawan, I. G. A. (2013). Pengaturan Penghentian Pemakaian Indikasi Geografis Pada Merek Terdaftar Oleh Pihak Lain Yang Tidak Berhak (Studi Komparatif Beberapa Negara). Jurnal Magister Hukum Udayana (Udayana Master Law Journal), 2(2), 1-17. https://doi.org/10.24843/JMHU.2013.v02.i02.p09

Ukas. Svinarky, .Jamba. (2017). Efektivitas Undang-Undang Nomor 15 Tahun 2001 Tentang Merek Terhadap Daftar Merek Usaha Dagang Industri Kecil Dan Menengah. Jurnal Cahaya Keadilan, 5(1), 29-47

Sasongko, W. (2012). Indikasi Geografis: Rezim HKI Yang Bersifat Sui Generis. Jurnal Media Hukum, 19(1).

\section{$\underline{\text { Desertasi }}$}

Ardian, A. V. (2008). "Prospek Perlindungan Hukum Hak Kekayaan Intelektual Dalam Kesenian Tradisional Di Indonesia." Disertasi. Program Pascasarjana Universitas Diponegoro.

\section{Peraturan Perundang-undangan}

Undang-undang Nomor 5 Tahun 2001 tentang Merek

Undang-undang Nomor 20 Tahun 2016 tentang Merek dan Indikasi Geografis 